\title{
25 RECIRCULATION OF NUTRIENTS FROM MSW WITH A BIOCELL REACTOR TECHNIQUE
}

\author{
Torleif Bramryd \\ Department of Ecology, University of Lund, Ecology Building \\ S-223 62 Lund, SWEDEN
}

\begin{abstract}
Biological treatment of wastes is an important part of a sustainable waste management system, and can be used for the extraction of nutrients, humus and energy, but also for longterm stabilization or detoxification of wastes. New biological techniques, like some types of reactor cells, constructed in landfill areas, also function as bio-filters, where nutrients are separated in a liquid form while heavy metals and other pollutants are fixed in the fermentation residue. Energy is extracted as biogas. Thus not only source separated, nonpolluted organic wastes, but also slightly polluted residual municipal, commercial or light industrial wastes can be treated and stabilized with biological techniques.
\end{abstract}

\section{KEYWORDS}

Waste, bioreactor cell, landfill, fermentation, leachates, nutrient, recovery, energy forest, biological treatment.

\section{INTRODUCTION}

A sustainable waste treatment philosophy should as much as possible resemble natural ecological processes, to achieve as closed systems as possible. This will reduce the risks for negative environmental effects like over-saturation and spreading of pollutants. Natural processes can both be used to extract energy and nutrients from different waste fractions, but can also be used to stabilize or detoxify polluted fractions.

An integrated waste treatment system aiming at nutrient and/or energy recovery can for example include aerobic composting of mixed or source separated wastes, anaerobic reactor fermentation or fermentation in bioreactor cells constructed in landfills. Each technique is normally appropriate for a certain spectrum of wastes. In addition to this, non-polluted fractions, like non-painted wood, tree-trimmings, a.s.o. can be used as a fuel in thermal energy plants. If only non-polluted waste fractions are used the ashes can be recycled back to forestry, horticulture or agriculture as fertilizer. Thus in addition to energy recovery also an eco-cycling of nutrients is achieved. It is thus of great importance to identify the best available options for different types of wastes.

\section{ECOLOGICAL EFFECTS OF WASTE TREATMENT}


In a modern society most of the products from agriculture and forestry are transported into urban areas. Therefore it is of ultimate importance to achieve an eco-cycle, where especially nutrients can be brought back to the producing ecosystems. An increased recovery of rest products as raw material for new products will decrease the need to exploit new natural resources, like minerals, oil and other materials, which have been stored in the ground. However not only material recovery will save natural resources. Circulation of nutrients from products in the urban society to agriculture and forestry will decrease the need for commercial fertilizers, and thus the use of long-term accumulated nutrients from the ground. The energy needed for the fixation or refinery of these commercial fertilizers will also be saved. Nutrients can either be circulated in a solid form as compost, bio-residues from fermentation, ashes or in a liquid form as leachates from landfill bioreactors.

It would be a severe mistake to forget the absolute necessity of landfilling as an accumulating process in a natural eco-cycling. As long as new resources are taken up from the ground as minerals, or as fossil organic matter, it is necessary, from an ecological point of view, to balance for the excess of substances that might occur in the eco-cycle. Otherwise there is an obvious risk for different types of over-saturation effects. A good example is the increased atmospheric $\mathrm{CO}_{2}$ concentrations as a result of the industrialization. This is due to burning of fossil fuels, increased harvest of forests and new techniques in agriculture with e.g. deeper ploughing and an increased use of nitrogen fertilizers. In order to reduce the risk for climatic effects and other disturbances it is of great importance to stimulate processes that withdraw carbon from the atmosphere.

Sanitary landfilling is a major process for accumulation of organic carbon, and landfilling thus can be compared to the natural peat or sediment forming processes in peatlands, lakes and marine environments. Landfilling could also be an essential process to balance for increased amounts of minerals, which can give toxic effects to the natural ecological balance. However to make this possible, and to avoid environmental hazards resulting from liquid or gaseous emissions from the landfill, it is of great importance to optimise the control over the landfill and its biological processes, and to optimise the biological and chemical immobilization of different substances in the landfill.

From an ecological point of view composting can be compared to the natural degradation of organic matter in most aerobic ecosystems. Most of the organic matter is degraded over a longer or shorter time, at the same time as the nutrients are mineralised to fractions available for plant uptake.

Anaerobic fermentation can be compared to the situation in marshlands and other waterlogged areas, where methane is produced. However due to the fact that the methane is collected and used as an energy source in all controlled fermentation techniques for waste, the product finally emitted to the atmosphere is $\mathrm{CO}_{2}$. After fermentation of source separated organic wastes the fermentation residue is normally treated aerobically to compost. Thus the final end-result from fermentation of waste in most cases is similar to that after aerobic composting. In a waste treatment technique based on a natural eco-balance composting and fermentation should be the main routes for treatment of wastes containing organic matter.

In natural ecosystems waste incineration corresponds to forest fires and the natural burning of savannas, grasslands or heath-lands. In these rather limited numbers of ecosystems fire is naturally used to mineralise nutrients from litter and other plant material, and thus promotes regeneration and activation of the ecosystem. The ashes contain easily available nutrients, at the same time as they produce an increase in soil $\mathrm{pH}$. In a system controlled by Man incineration should only be used for rest-products that will leave ashes with such low concentrations of heavy metals and other pollutants, that a re-circulation of the ashes to e.g. forests is possible. If a mixed and polluted waste is burnt, the total amount of nutrients is lost 
in a contaminated ash, which must be landfilled in sealed and carefully controlled mono-fills. Thus in a city with mass-incineration as the main route for waste disposal, almost the whole stream of nutrients, which has been transported into the society from agriculture or forestry, will be lost in toxic ashes. Main problems with incineration of wastes mixed with polluted material are also the risk for polluted gas emissions and that e.g. heavy metals will be more available for leaching from the ashes.

\section{TECHNICAL PERFORMANCE}

\section{1 Reactor-cell fermentation of non-polluted org wastes}

\section{1. 1 Reactor-cell design}

Reactor-cell fermentation is a static process where the waste is treated in chambers constructed in the ground, e.g. in landfill areas, without any equipment for pumping. This technique can be an alternative to fermentation in steel reactors, especially when the waste is inhomogeneous.

Reactor-cell fermentation means a controlled process in a more or less sealed environment. Several types of cell constructions have been proposed during the years in order to obtain a system that does not require a reactor tank fermentation process. However, the construction of a bioreactor cell can be performed as simple as possible as long as the cell can be guaranteed full stability during the life-time of the fermentation process. Cells made of concrete seem to over-emphasize the need for a sealed system. Instead natural materials, such as clay, or plastic liners normally are excellent substitutes, serving as a barrier. A steel frame construction resting on natural soil and coated with wooden debris could be another alternative. A plastic liner, or a layer of compressed, mixed recycled plastics, should then be placed in the bottom.

\section{1. 2 Construction of reactor-cells}

The size of a reactor-cell for organic wastes is a function of the annual volumes of waste. The fermentation process starts after one or two months, which means that the methane gas extraction system should be working as early as possible.

In the bottom section of the cells, drainage pipes for leachates are placed. The application of the organic waste should be made in layers to simplify the construction of gas collection tubes. One bio-reactor cell should be completed within one year, in order to avoid migration of gases to the atmosphere. After having placed the organic waste in layers and inserted gas drainage pipes at every two or three meter interval the cell is sealed off with a thick layer of dense material. Before this, it is important to place hoses on top of the waste in order to maintain control of moisture. The amount of water should be based on the amount of leachates collected in the bottom of the cell. Excess water should be recycled in order to minimize later treatment of leachates. The household waste contains organic matter rich in nitrogen, why wood-chips of paper with a high carbon content should be used to balance the $\mathrm{C} / \mathrm{N}$ ratio. An optimal $\mathrm{C} / \mathrm{N}$ ratio should be around 40:60.

In general the amount of produced biogas could be expected to be around $250 \mathrm{~m}^{3}$ per ton waste. Normally the methane concentrations in collected biogas are expected to be around 65$68 \%$.

\section{1.3 Excavation of cell material}


When the biogas production has started to decrease it is time to proceed with the posttreatment process. This process is defined as an aerobic stabilization process, where the fermentation residues are composted.

After composting the material should pass a wind drum and magnetic separator unless the purpose of producing compost for landfill cover. The aerobic stabilization will take some three to five months to complete before it could be subject to commercial use.

\section{2 Bio-reactor cell fermentation of mixed residual wastes}

\section{2. 1 Construction of bioreactor cells}

Fermentation in reactor cells constructed in landfills is a technique to recover energy and nutrients from residual solid wastes, left after material recovery and source separation of an organic fraction suitable for conventional reactor fermentation or aerobic composting. In this case the fermentation residues should not be excavated, but be left in the landfill. Bio-energy is extracted with collected biogas, and nutrients are extracted through collected leachates. Due to the fact that heavy metals, in contrary to light metals (nutrients), form very stabilized sulphides under anaerobic conditions, the concentrations of heavy metals are very low in the leachates from bioreactor cells.

The technique is very common in United Kingdom, United States, Sweden, Holland, Germany, Australia, South Africa, a. s. o.. The extraction of energy (for electricity, heat and motor fuel) is important in most countries, while the extraction of nutrients is more essential in countries with leaching soils and low nutrient budgets.

Each reactor cell consists of a well-defined unit, normally with separate gas and leachate collection systems. The bottom of the cells should be covered by a layer with low permeability (clay, bentonite, plastic liners or layers of recycled polyethylene plastics). The reactor cells are surrounded by clay walls, which during the filling period serve as a shield against insight and as a protection against windblown paper and plastics.

Every reactor cell has a separate gas collection system consisting of horizontal drains in every second lift. The horizontal drains are placed 30-50 m apart from each other. Each cell should also have a separate collection system for leachates. The processes in the reactor cell are continuously monitored, and it is possible to control the processes by different actions. The process can be regulated by additions of nutrients, limed water or by regulating the temperature, a. s. o..

The size of the reactor cells depends on the amount of waste applied per day. As a rule one reactor cell should be filled within 2 years. In order to avoid diffuse transportation of methane to the atmosphere, the open, active surface should be as small as possible, and the collection of methane should start already during the filling period. In a large and developed biogas system the relatively low methane content of the gas collected from the fresh waste is normally compensated by the high methane content from older parts of the reactor cell or landfill.

In order to improve the transportation of methane gas and leachates in the reactor cell, clay and sand should be avoided. Thus woodchips or waste wood homogenized by the compactor wheels can be used for the construction of roads within the bioreactor, as a substitute for sand and gravel. Waste wood, bark, the coarse fraction from sieving of compost or any related material can be used for the daily cover. This cover material will take part in the biological reactions and will contribute to the produced methane gas or to the nutrients collected through the leachates. This is thus an environmentally friendly way to use painted or impregnated wood (demolition wood), furniture, etc, which due to a high contamination of heavy metals should not be burned. In this way the energy will be recovered through the methane gas, while 
the heavy metals will be firmly fixed to the fermentation rest, left in the landfill.

Each cell in the landfill bioreactor should be closed with a clay cover or related material, which will decrease the amounts of air that might penetrate the reactor cells during the underpressure that is established during the extraction of the methane gas from the cells. This cover will also decrease the amounts of leachates. A layer of compacted source-separated wasteplastics (polyethylene) has a similar function. If a thick vegetation cover can be established on top, this will also decrease the amounts of leachates.

\section{2. 2 Extraction of energy}

During anaerobic degradation of the organic matter in the reactor cell biogas is produced. The methane concentration depends largely on the type of waste. A mixture of municipal, commercial and light industrial waste, as well as smaller amounts of source separated, biodegradable fractions from construction and demolition waste, has been shown to give the best yield of methane gas. The chemical composition of the waste determines the gas composition, i.e. the relations between organic carbon and nitrogen ( $\mathrm{C} / \mathrm{N}$ ratio), carbon and phosphorus ( $\mathrm{C} / \mathrm{P}$ ratio) and the ratios between nitrogen/magnesium and potassium/calcium. Also the moisture content and the physical structure are of great importance. Thus it is essential with a mixture of food waste and material rich in cellulose (paper, wood, a.s.o.). Plastics, on the other hand, can help to decrease the amounts of air penetrating down in the waste and thus facilitate stabilized anaerobic conditions.

Polystyrene cups and related hard plastics can act as stabilizers in the landfill bioreactor facilitating the transportation of methane to the extraction points. Also other coarser material like crushed furniture and other waste wood can act as such stabilizing material. In wet and homogeneous waste without structure material, there is a risk of building up zones with a poor water drainage capacity. Here the production of organic acids can lead to decreasing $\mathrm{pH}$ levels and decreased methane production. Such wet zones also prevent the gas transportation. Normally a $\mathrm{C} / \mathrm{N}$ ratio of about $50-70$ is regarded as optimal for landfill reactor cell fermentation. This is a higher ratio than is normally optimal in steel reactor fermentation. Food waste normally has a $\mathrm{C} / \mathrm{N}$ ratio of about 20 . This means that the cellulose content in the solid waste (paper- and wood products) is of great importance as a carbon source during the methane production. Thus separation of municipal waste in a wet and a dry fraction, where the wet fraction is intended for reactor cell treatment, will give a much lower yield of methane than if the mixed waste was fermented in the reactor cells. A low $\mathrm{C} / \mathrm{N}$ ratio will probably cause an accumulation of fatty acids, intermediate substances formed during the methane formation process.

The relatively low demands of nurrients for the landfill reactor cell fermentation process further means that separation of food waste for reactor fermentation or composting does not negatively effect the possibilities for landfill reactor cell fermentation. The reactor cell fermentation is sooner an alternative to mass-incineration than to composting or reactor fermentation.

The total annual amount of biogas extracted from reactor cells is estimated to approximately $200-250 \mathrm{~m}^{3}$ per ton landfilled waste, or about $15-25 \mathrm{~m}^{3}$ of biogas per ton waste and year. The biogas presents a methane concentration of about $40 \%$ already a few months after landfilling, and reaches after about 1-2 years a stable value of about $60-65 \%$ methane. Due to a longer available process time cellulose in optimised landfill reactor cells is hydrolysed, and the total yield can be expected to be almost twice as high, compared to fast steel-reactor fermentation.

\section{2. 3 Separation of nutrients}


Stabilized anaerobic conditions result in an effective immobilization of heavy metals and other pollutants. In a stabilized anaerobic environment most heavy metals, in contrast to nutrients like magnesium, potassium, sodium and calcium, form insoluble sulphides. Due to these different chemical characteristics most of the nutrients will appear in the leachates, while most of the heavy metals will be bound in the fermentation rest, which is left in the landfill. Thus the reactor cell acts like an anaerobic filter, enabling a separation of the nutrients from a mixed waste. If the leachates are used as fertilizer in e. g. energy plantations, forestry, a. s. o., the nutrients can be brought back to an ecological cycling. This possibility will not be offered after incineration, where the ashes, due to the high amounts of easily available heavy metals, are recommended to be landfilled in sealed mono-fills.

Questions remain concerning if the stimulated degradation processes will decrease the availability of heavy metals at a longer time scale. Under anaerobic conditions lignine does not degrade and will form a structural organic matter, which will provide for high moisture content, on a long-term basis. The reactor cell therefore will have an environment similar to peatlands. The organic matter is enough to retain the heavy metals in the fermentation rest, left in the landfill, through chemical and complex bindings. Most of the methane gas will be extracted during a 10-15 year period. However also after this period anaerobic conditions will probably dominate over an extensive time scale. Further many landfills are placed in depressions or wetlands, and it is relevant to believe that much of the minerals left after a future reduction of the organic contents, still will be bound up under anaerobic conditions. This is of ultimate importance for the extraction of nutrients, as mentioned above. This also means that the reactor cells should not be excavated, as this would lead to oxidation of the metal sulphides, and thus to mobilization of heavy metals to the leachates. The fermentation rest should instead be left in the landfill.

Due to settings in the landfill during mineralization of the waste, up to $50 \%$, additional space is achieved. New reactor cells can thus be constructed on top of the old ones, and the fermentation rest containing a concentrate of heavy metals, organic carbon from fossil material like plastics and rubber, efficiently will be long-term accumulated. This is important from a biogeochemical point of view.

At a landfill in Helsingborg, South Sweden, a full-scale nutrient recovery system started during 1995. The leachates from the reactor cells are transported to a young birch forest (Betula pubescens) where the leachates are spread on the soil surface with a system of perforated pipelines distributing the leachates at intervals. Birch has a very good capacity to evaporate water and the potential for increased biomass production during increased amounts of available nutrients is extremely good. In addition to this birch forest also plantations with willow (Salix viminalis), grasslands and meadows can be used to extract the nutrients from the leachates and for evaporation of the water.

\section{CONCLUSIONS}

* Fermentation of solid wastes in landfill reactor cells is an environmentally attractive technique for energy and nutrient extraction from mixed residual solid wastes. Landfill

bio-reactor cells produces approximately $20 \mathrm{~m}^{3}$ biogas per ton waste and year, or totally about

$150-250 \mathrm{~m}^{3}$ biogas per ton waste during $8-10$ years.

* Heavy metals are immobilized in anaerobic landfill reactor cells, resulting in low concentrations in the leachates. The reactor cell thus functions as a bio-filter, where nutrients are separated from heavy metals. 